\title{
REGULATION OF POLYUNSATURATED FATTY ACIDS ACCUMULATION AND CHARACTERIZATION OF LINOLENIC ACID AFTER GERMINATION OF SUNFLOWER SEED
}

\author{
Rabiei, Z., Tahmasebi Enferadi, S. and Vannozzi, G.P. ${ }^{*}$
}

Dipartimento di Scienze Agrarie e Ambientali, Università degli Studi di Udine, via delle Scienze 208, 33100 Udine, Italy

Received: October 10, 2006 Accepted: May 15, 2007

SUMMARY

The metabolism of triacylglycerols (TAG) and their conversion into new triglycerides and polar lipids such as linolenic acid take place during the first phase of development of Helianthus annuus L. seed after seeding. Oleate desaturase and linoleate desaturase are two major enzymes responsible for the synthesis of these compounds. To determine whether enzymatic mechanisms function the same in catabolizing seed store lipids of normal and mutant sunflower lines, modifications of fatty acids composition of seeds and the initial stages of growth (seeding-VE) cultivated under conditions of controlled temperature were assessed. The increase of linoleic acid content during all stages of development in a mutant line revealed a higher activity of oleic acid desaturase $\left(\Delta^{12}\right.$-desaturase) in transforming oleic acid to linoleic acid probably due to higher availability of the substrate of this enzyme in this line; however, its amount increased moderately in a normal line. The activity of FAD2-3 in developing sunflower seeds is recognized even two days after seeding (DAS) in both lines; however, linolenic acid accumulation starts seven DAS.

Key words: sunflower, triacylglycerols, oleate desaturase, linoleate desaturase, oleic fatty acid, linoleic fatty acid

\section{INTRODUCTION}

Most of the triacylglycerols are hydrolyzed in the first 10 DAS depending on the action of lipase (Ichihara et al., 1980). Different types of desaturases cause increases in saturation ratio: oleic acid desaturase (membrane-bound enzyme FAD2; EC 1.3.1.35) (Shanklin and Cahoon, 1998) and linoleic acid desaturase, which are present in the endoplasmic reticulum of the cytosol (ER fad2 and ER fad3, respectively) and plastid fad 6 and plastid fad7 in the chloroplasts, which are

* Corresponding author: e-mail: vanozzi@uniud.it 
responsible of the modification of oleic acid to linoleic acid and linoleic acid to linolenic acid, respectively (Mollers, 2002). This enzyme catalyzes the first extra-plastidial desaturation in plants, converting oleic acid, preferentially esterified in the sn2 position of phosphatidylcholine, to linoleic acid. The reaction involves the concomitant reduction of molecular oxygen to water and requires the presence of $\mathrm{NADH}, \mathrm{NADH}$-cyt $b 5$ reductase and cyt $b 5$ as electron donor systems (Smith et al., 1990).

FAD2 (FAD2; EC 1.3.1.35) (Shanklin et al., 1994) uses 1-acyl-2-oleoyl-sn-glycero-3-phosphocholine as a substrate (Stymne and Appelquist, 1978) and it requires oxygen, NADH as a reductant (Vijay and Stumpf, 1972), NADH:Cyt b5 oxidoreductase and Cyt b5 (Smith et al., 1990) to produce the polyunsaturated fatty acids linoleate (cis 9,12-18:2) and alpha-linolenate (cis 9,12,15-18:3). Those are major acyl groups found esterified to compounds present in plant membrane lipids.

It is well known that environmental temperature during oilseed development modifies the proportion of linoleic acid (Graces et al., 1992; Martinez-Rivas et al., 2000) depending on the geographical area and year, resulting in an unwanted variation of the oleic to linoleic ratio in the final composition of the oil (Canvin et al., 1965). High temperatures decrease the linoleic acid content of oilseed oils. However, the duration of this temperature effect varies with plant species, while in sunflower seeds the percentage of linoleic acid is highly influenced by growth temperature (Lajara et al., 1990). Indeed, a cold-inducible plastid $\omega$-3 desaturase gene (FAD7) has been isolated from Arabidopsis (Gibson et al., 1994). In Arabidopsis, microsomal $\omega-6$ desaturase is encoded by a single FAD2 gene, and expression of this gene is not regulated by low growth temperature (Okuley et al., 1994).

Thus, in soybean plants, the decrease in 18:1 content in seed lipids at low temperature may not be due to the transcriptionally induced or enhanced expression of $\omega-6$ desaturase gene.

The FAD2-1 gene is strongly expressed in developing seeds, whereas the FAD22 gene is constitutively expressed in both vegetative tissues and developing seeds. Thus, the FAD2-2 gene-encoded $\omega-6$ desaturase appears to be responsible for production of polyunsaturated fatty acids within membrane lipids in both vegetative tissues and developing seeds. The seed-specifically expressed FAD2-1 gene is likely to play a major role in controlling conversion of oleic acid to linoleic acid within storage lipids during seed development. In both soybean seed and leaf tissues, linoleic acid and linolenic acid levels gradually increase as temperature decreases. However, the levels of transcript for FAD2-1, FAD2-2, and the plastidial $\omega-6$ desaturase gene (FAD 6) do not increase at low temperature. These results suggest that the elevated polyunsaturated fatty acid levels in developing soybean seeds grown at low temperature are not due to the enhanced expression of $\omega-6$ desaturase genes (Heppard et al., 1996).

There are traceable quantities of linoleic acid $(0.1 \%$ or trace) in sunflower seed whereas an abundant amount of linolenic acid was found in green tissues of the 
plant, which was associated with cellular and sub-cellular membranes (Salisbury and Ross, 1988).

High-oleic sunflower (HOA) made a widespread industrial utilization in food and non-food sectors. Technical application of HOA depends on its storage conditions. Humidity causes germination that makes active enzymes responsible for oleic acid transformation to linoleic acid. The aim of this study was to determine the effect of early germination due to high storage humidity on the expression of fatty acid desaturases (FAD) and consequently the production of linolenic acid as a polyunsaturated fatty acid that plays an important role in decreasing the stability of oil extracted from those germinated seeds. The expression of FAD was identified by cDNA synthesized from mRNA isolated from samples, alternatively, linolenic acid accumulation was measured with gas chromatography.

\section{MATERIALS AND METHODS}

Normal-type sunflower (Helianthus annuus L. cv. HA-89) a restorer inbred line released by Dr. J. F. Miller at Fargo, ND, USA, and high-oleic sunflower inbred line $\mathrm{R}$ 978, a restorer inbred line selected at the University of Udine from material coming from Pervenets, and kindly supplied by Prof. Vannozzi.

The half-seed analysis of Conte et al. (1986) was applied. Seeds were cut transversally. The portions containing the embryos were germinated and the other halves were used for fatty acid composition assessment by GC.

Total fatty acid composition was determined with a HRGC Mega 2, Fisons gas chromatograph equipped with a split injection system and flame ionization detector (FID), a fused-silica capillary column $30 \mathrm{~m} \times 0.32 \mathrm{~mm}$ i.d. The percentages of fatty acids were obtained by integrating the peaks with Chrom-Card, Fisons Ins. Software.

Samples at different stages of sunflower development (2-25 DAS) were harvested and used for RNA isolation. Total RNA and mRNA were isolated with the SV Total RNA Isolation System Kits (Promega) and Qiagen OligoTex mRNA Mini Kit (Promega), respectively, according to the manufacturer's instructions. cDNA was prepared according to the Reverse Transcription System (Promega).

In this study we used a two-way ANOVA (completely randomized design) with 10 replicates. The first factor (A) was days after seeding (in seed, 2, 7, 12, 18, 25 DAS). The second factor (B) was genotype, which included two inbred lines, LOAC and HOAC.

\section{RESULTS AND DISCUSSION}

The results of the GC analysis demonstrated that the two inbred lines had completely different metabolisms of fatty acids during all phases of growth, even in the case of linolenic acid whose amount in seed was about zero in both lines. 
The values of palmitic and stearic acids during seed development were the same in both lines and there were no significant differences in any of the phases of sunflower seed development, which implies that the genotype (low-oleic or higholeic) had no effect on the metabolism of this fatty acid during the experimental period (seeding to VE).

It seems worthy to note that stearic acid can transform to oleic acid by the action of $\mathrm{D}^{9}$ desaturase as described by Arao and Yamada (1994).

In the LOAC line, the oleic acid content as a monounsaturated acid and also as a substrate for oleate desaturase was $42 \%$ and it remained constant during the first 3 days after seeding, but it gradually decreased to $35 \%$ on the $7^{\text {th }}$ day as a result of oleate desaturase action.
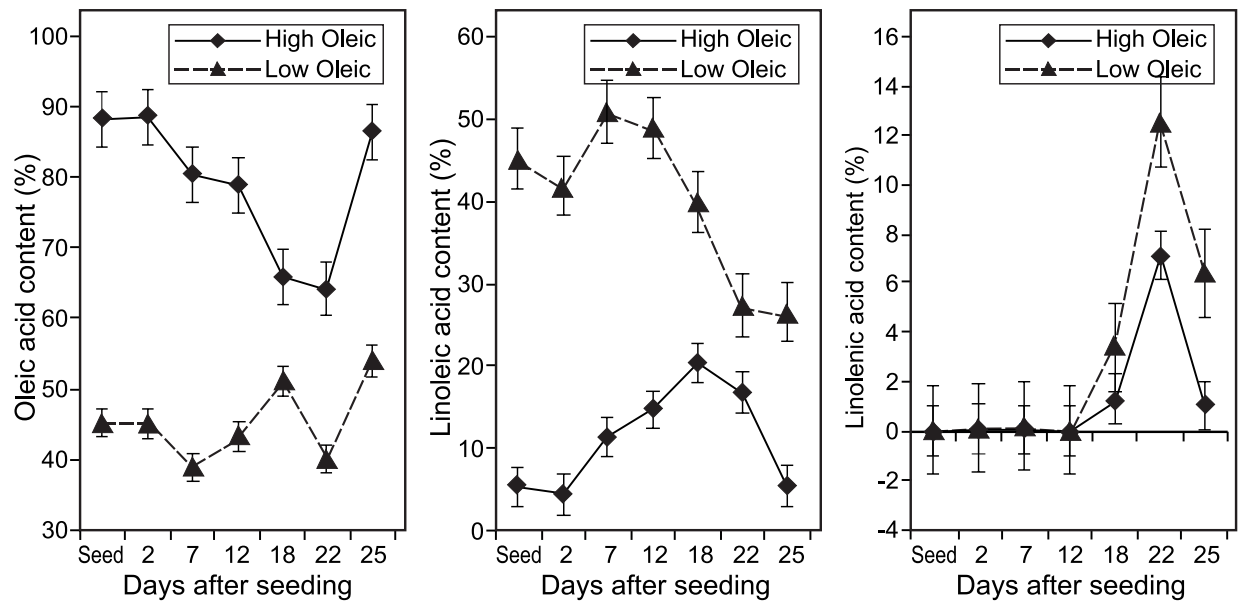

Figure 1: The modification of fatty acids in HA 89 and R 973 sunflower genotypes during 25 DAS oleic acid (a), linoleic acid (b), linolenic acid (c)

The linoleic acid content revealed a primary reduction until $3^{\text {rd }}$ DAS, then a $9 \%$ increase on the $7^{\text {th }}$ DAS. During the rest of the experiment, continual reduction of linoleic acid was observed. The contiguous decrease of linoleic acid and increase of linolenic acid took place during 7-18 DAS which was predictable and normal (Figures 1a, b, c). After that phase, the linoleic acid content decreased. This phenomenon could be explained as the disactivation of linoleate desaturase and/or the initiation of anabolism of 18:4 ( $D^{6}$-desaturase) and 20:3 (D ${ }^{6}$-elongase).

In the HOAC line, oleic acid catabolized ( $35 \%$ reduction) until the $22^{\text {nd }}$ DAS which coincided with the $17 \%$ increase of linoleic acid and $7 \%$ increase of linolenic acid (Figures 1a, b, c).

In the last phase (VE), an increase of oleic acid and decreases of linoleic and linolenic acid were observed. This could explain the specific expression of FAD2 class in sunflower whose behavior was not similar to this class in other oil plants such as soybean. 
In soybean the FAD2-1 gene is specifically induced during seed development when the rate of storage lipid synthesis is at a maximum. In contrast, the FAD2-2 gene was constitutively expressed in both vegetative tissues and throughout seed development, although the highest expression level was found in leaf tissues. The composition of fatty acids in developing seeds is regulated by developmental stage and growth temperature; however, expression of FAD2-1 and FAD2-2 genes controlling the fatty acid desaturation was not induced or enhanced by cold temperature.

It is worthy to follow FAD2 class expression in seed development to justify the fluctuation of fatty acid content and its dissimilarity between low and high oleic acid lines.

We designed an effective primer pair of FAD2 class capable of amplifying a fragment of $674 \mathrm{bp}$ from Helianthus annuus L. species. The region selected for specific amplification of FAD2-3 is shown in Figure 2.

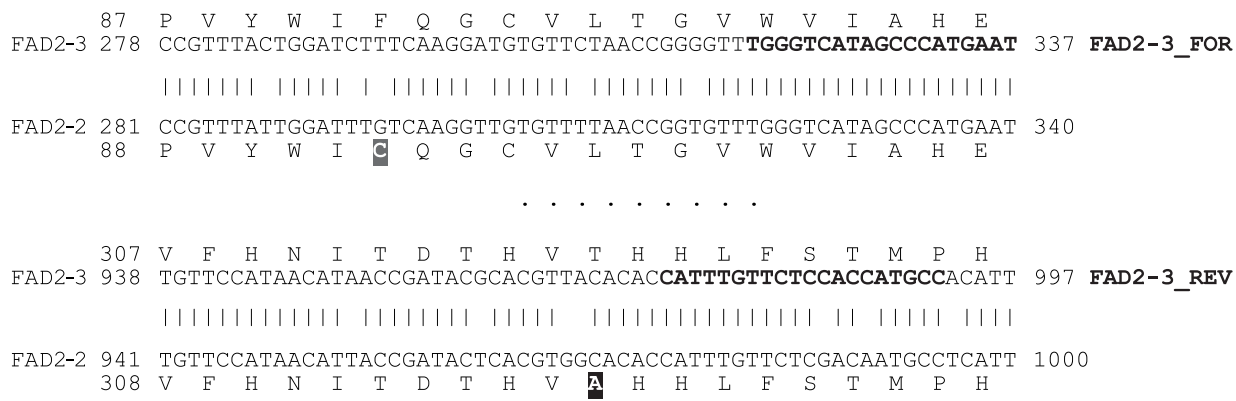

Figure 2: BLAST analysis of 720 bases of FAD2-2 and FAD2-3 sequences. Above and below, the two sequences of CDS translation are shown. The designed primer is bold dark blue. Different aminoacids are evidenced in reverse color. The middle part of the blast was cancelled.

PCR amplification of cDNA for detection of FAD2-3 gene expression was carried out (Figure 3). To establish definitively that the designed primer represents the FAD2-3, a constitutive gene like ubiquitin (GUbB1) was used.

$\begin{array}{llllllllllllll}700 \mathrm{bp} \rightarrow & 1 & 2 & 3 & 4 & 5 & 6 & 7 & 8 & 9 & 10 & 11 & 12 \\ 600 \mathrm{bp} \rightarrow & \end{array}$

Figure 3: Agarose gel electrophoresis of the two sunflower genotypes (high- and low-oleic acid) of different growth stage (seeding to VE) on FAD2-3 sequence. Lane 1 ladder; lanes 2-5 high oleic genotype in seed 2,5,9,14 DAS, respectively ; lanes 6-9 low-oleic genotype in seed 2,5,9,14 DAS, respectively; lanes 10, 11 DNA of HOAC and LOAC respectively; lane 12 blank control (PCR mixture without DNA template). Lane 5 and 9 indicate inactivation of gene FAD2-3 at this stage.

FAD2-3 is expressed immediately after soaking the seed in water for germination and accumulation of linolenic acid occurs before the $20^{\text {th }}$ DAS, and afterwards 
this gene is not expressed any more (Figure 3). In fact, the transcript of the FAD2-3 gene was moderately expressed in developing seeds, but at four true leaves stage it would be blocked.

\section{CONCLUSIONS}

The changes of oleic, linoleic and linolenic acids at the vegetative stage in both lines were significant, which could be related to FAD2 and FAD3 activity.

Linoleic acid as a substrate for linoleate desaturase increased during all stages of development only in the mutant line which revealed a higher activity of oleic acid desaturase $\left(\Delta^{12}\right.$-desaturase) for transforming oleic acid to linoleic acid than the low oleic acid line, probably due to the low availability of the substrate of this enzyme in the low oleic acid line. Quantitative analysis may be conducted using RT-PCR.

FAD2-3 is expressed in seeds two days after seeding for germination and accumulation of linolenic acid occurs till the $20^{\text {th }}$ DAS, and afterwards this gene is not expressed any more.

\section{ACKNOWLEDGMENT}

This work was supported by grants from the Regione Autonome Friuli Venezia Giulia for development of the inter-regional project "Sviluppo di nuove per la produzioni no-food (olio industriali, fibra, cellulose ed amidi) con studi e ricerche sulle technologie e sulla razionalizzazione dei processi e dei sistemi produttivi" and the support of Prof. Giovanardi is gratefully recognized. The technical assistance of Dr. Slobodanka Radović in the use of the SV Total RNA Isolation System Kit, Qiagen OligoTex mRNA Mini Kit and Reverse Transcription System is gratefully recognized.

\section{REFERENCES}

Arao, T., Yamada, M., 1994. Biosynthesis of polyunsaturated fatty acids in the marine diatom. Phaeodactylum triconutum. Phytochemistry 35: 1177-1181.

Canvin, D.T., 1965. The effect of temperature on the oil content and fatty acid composition of the oils from several oil seed crops. Can. J. Bot. 43: 63-69.

Conte, L.S., Leoni, O., Palmieri, S., Lercker, P., 1989. Half-seed Analysis: Rapid Chromatographic Determination of the Main Fatty Acids of Sunflower Seed 1989. Plant Breeding 102, 158-165.

Gibson, S., Arondel, V., Iba, K., Somerville, C.R., 1994. Cloning of a temperature-regulated gene encoding a chloroplast $\omega-3$ desaturase from Arabidopsis thaliana. Plant Physiol. 106: 1615-1621.

Graces, R., Sarmiento, C., Mancha, M., 1992. Temperature Regulation of Oleate Desaturase in Sunflower (Helianthus annuus L.) Seeds. Planta 186: 461-465.

Heppard, E.P., Kinney, A.J., Stecca, K.L., Miao, G.H., 1996. Development and growth temperature regulation of two different microsomal $\omega-6$ desaturase gene in soybeans. Plant Physiol. 110: 311-319. 
Ichihara, K.I., Noda, M., 1980. Fatty Acid Composition and Lipid Synthesis in Developing Safflower Seed. Phytochemistry 19: 49-54.

Lajara, J.R., Diaz, U., Quidiello, D.R., 1990. Definite influence of location and climatic conditions on the fatty acid composition of sunflower seed oil. J. Am. Oil. Chem. Soc. 67: 618-623

Martinez-Rivas, L.M., Gracia-Diaz, M.T., Mancha, M., 2000. Temperature and oxygen regulation of microsomal oleate desaturase (FAD2) from sunflower. Biochemichal Society, 28: 890892.

Mollers, C., 2002. Development of high oleic acid oilseed rape. Presentation at the $8^{\text {th }}$ International Conference for Renewable Resources and Plant Biotechnology. Narossa R 2002. Magdeburg, 10-11. June; published on CD only (Proceedings).

Okuley, J., Lightner, J., Feldmann, K., Narendra, Y., Lark, E., Browse, J., 1994. Arabidopsis FAD2 gene encodes the enzyme that is essential for polyunsaturated lipid synthesis. The Plant Cell 6: 147-158.

Salisbury, F.B. and Ross, C.W. 1988. Fisiologia Vegetale. Belmont, California, pp. 219-279.

Shanklin, J., Cahoon, E.B., 1998. Desaturation and related modification of fatty acids. Ann. Rev. Plant Physiol. Plant Mol. Biol. 49: 611-641.

Shanklin, J., Whittle, E., Fox, B.G., 1994. Eight Histidine Residues are Catalytically Essential in a Membrane-associated Iron Enzyme, Stearoyl-coa Desaturase, and are Conserved in Alkane Hydroxylase and Xylene Monooxygenase. Biochemistry 33: 12787-12794.

Smith, M.A., Cross, A.R., Jones, O.T.G., Griffiths, W.T., Stymne, S., Stobart, K., 1990. Electrontransport components of the 1-acyl-2-oleoyl-sn-glycerol-3-phosphocoline $\mathrm{D}^{12}$-desaturase ( $\mathrm{D}^{12}$-desaturase) in microsomal preparations from developing safflower (Carthamus tinctorius L.) cotyledons. Biochem J. 272: 23-29.

Stymne, S., Appelqvist, L.A., 1978. The Biosynthesis of Linoleate from Oleoyl-coa via Oleoylphosphatidylcholine in Microsomes of Developing Safflower Seeds. Eur. J. Biochem. 90: 223-229.

Vijay, I.K., Stumpf, P.K., 1972. Fat Metabolism in Higher Plants. 48. Properties of Oleyl Coenzyme A Desaturase of Carthamus tinctorius. J. Biol. Chem. 247: 360-366.

\title{
REGULACIÓN DE ACUMULACIÓN DE ÁCIDOS GRASOS POLI-NOSATURADOS Y CARACTERIZACIÓN DEL ÁCIDO LINÓLICO DESPUÉS DE GERMINACIÓN DE LA SEMILLA DE GIRASOL
}

\author{
RESUMEN
}

El metabolismo de triacilgliceroles (TAG) y su conversión en trigliceridos y lípidos polares, como el ácido linólico, se despliegan en la primera fase de desarrollo de la semilla Helianthus annuus L. inmediatamente tras la siembra. Oleato desaturasa y linoleato desaturasa son dos enzimas más importantes, responsables para la síntesis de estas uniones. Para comprobar si los mecanismos enzimáticos catabolizan de la misma forma, los lípidos de reserva en la semilla de las líneas normales y mutantes de girasol, se evaluaron los cambios en la composición de los ácidos grasos en la semilla, durante las fases iniciales de crecimiento (siembra-VE) bajo las condiciones de la temperatura controlada. El contenido aumentado del ácido linólico en todas las fases de desarrollo de la línea mutante, indicaba una aumentada actividad de desaturasa del ácido oleico (D12-desaturasa) en la conversión del ácido oleico en el ácido linólico, lo más probable por causa de la aumentada accesibilidad del substrato de este enzima en esa línea; en la línea normal, mientras tanto, el contenido del ácido linólico fue moderadamente aumentado. La actividad de FAD2-3 en la semilla en desarrollo, pudo determinarse hasta dos días después de la siembra (DPS) en ambas líneas; pero, la acumulación del ácido linólico empieza 7 DPS. 


\title{
RÉGULATION DE L'ACCUMULATION DES ACIDES GRAS POLYINSATURS ET CARACTÉRISATION DE L'ACIDE LINOLÉIQUE APRÈS GERMINATION DE LA GRAINE DE TOURNESOL
}

\author{
RÉSUMÉ
}

Le métabolisme des triacylglycérols (TAG) et leur conversion en nouveaux triglycérides et lipides polaires ont lieu au cours de la première phase de développement de la graine de Helianthus annuus L. immédiatement après les semailles. L'oléate désaturase et le linoléate désaturase sont les deux enzymes responsables de la synthèse de ces composés les plus importants. Pour déterminer si les mécanismes des enzymes catabolisaient de la même manière les lipides de réserve dans la graine de lignées normales et mutantes de tournesol, on a évalué les changements dans la composition des acides gras de la graine au cours des phases initiales du développement (semailles-VE) dans des conditions de température contrôlée. L'augmentation du contenu d'acide linoléique au cours de toutes les phases du développement dans une lignée mutante a révélé une plus grande activité d'acide oléique désaturase (D12-désaturase) dans la transformation d'acide oléique en linoléique, probablement à cause d'une plus grande disponibilité du substrat de cette enzyme dans cette lignée; cependant, le contenu d'acide linoléique était augmenté modérément dans la lignée normale. L'activité de FAD2-3 dans la graine en développement a pu être établie même deux jours après les semailles (JAS) dans les deux lignées; cependant, l'accumulation d'acide linoléique débute 7 JAS. 